\title{
Development and Transformation of the Indian Nuclear Doctrine
}

\author{
Ashfaq Ahmed ${ }^{1}$, Muhammad Jawad Hashmi ${ }^{2}$, and Saima Kausar ${ }^{3}$
}

\begin{abstract}
Indian rationale for developing nuclear weapons is embedded in Article 51 of United Nations (UN) Charter. After analyzing the changes in Indian defence procurements, a huge defence spending and public statements issued by the former and incumbent Indian government official authors presume India is changing its nuclear posture. New Delhi is discarding earlier publicly stated No-First Use (NFU) posture with ready or super ready status. It is replacing Credible Minimum Deterrent (CMD) posture with overkill capacity. India revived earlier announced Cold Start Doctrine (CSD). The objective of this paper is to review changes in Indian nuclear doctrine and capabilities and implications for Pakistan security. However a qualitative method is used for the completion of this research. Paramount aim of nuclear signaling is to avoid outbreak of violence. The findings of this paper include dividing Indian strategic community into leftists/rightists. Further, abovementioned changes can result in Indian preemptive strike against Pakistan or inadvertent or unauthorized use of nuclear weapons. The region is ripe for nuclear exchange. South Asia is nuclear flashpoint. In conclusion, Pakistan needs to expedite its diplomatic efforts to highlight changes introduced by India. Islamabad should follow North Atlantic Treaty Organization (NATO) strategy to solidify its conventional and nuclear armed force structure to deter militarily powerful enemy.
\end{abstract}

Keywords: Nuclear Doctrine; Credible; Strategic; Community; No First Use.

\section{Introduction}

Doctrines are the decisive rules accentuating rightful connection between strategies and tactics. It translates power into policy and decides requisite degree of force required for achieving national cause (Kissinger, 1957). Doctrines arrange assistance to policymakers in routine affairs during peacetime, in crisis management and if requisite achieve national ambitions during war. It aids policymakers to take measures in pursuit to accrue or protect national interests. Military leadership begin or wind-up fatal missions in the light of military doctrines (Chapman, 2009). Sovereign states weigh strategic environment threat perception, economic disparity, geographical size,

\footnotetext{
${ }^{1}$ Department of Politics and International Relations (DPIR) University of Sargodha, Sargodha, Punjab, Pakistan.

${ }^{2}$ Department of Political Science \& International Relations University of Gujrat, Hafiz Hayat Campus, Gujrat, Punjab, Pakistan.

${ }^{3}$ Department of International Relations, Iqra University, Islamabad, Pakistan.

*)Corresponding Author.

Email: ashfaq.hameed@uos.edu.pk
} 
military preparedness and belief systems to develop and perpetuate national security strategy and doctrine (Sethi, 2004). In post 9/11 era, ideological wars (National Security Strategy, 2010) waged by non-state actors cannot be ignored. Inter-services competition, civil-military affairs and qualitative improvements in technology influences military doctrines.

Nuclear doctrine stimulates nuclear behaviour, expedite policies, prompt future course, specify force structure i.e., type and range of missile inventories. It holds the reins of nuclear forces in peacetime and specifies conditions for Weapons of Mass Destruction (WMDs) use. List of prerequisites for decision making procedure in Nuclear Weapon States (NWS) entail care, foresight and effectiveness (Synnott, 1999). However, evolution, progression and perfection of nuclear doctrines, vertical proliferation and nuclear commerce are weakening the Nuclear Non-Proliferation Treaty (NPT).

During crisis deterrent role of the WMDs and the gauge of nuclear signals increase. Paramount aim of nuclear signaling is to avoid outbreak of violence and keep its pace as low as possible. However, residual capacity of defending state's nuclear forces instills fear of punishment and deters aggression. Juvenile NWS work in three dimensions; they determine nuclear force structure, practical and declaratory policies (Sauer, 2009). Force structure guides NWS to regulate size, range and future requirements. Practicable tenets justify resolve and prospects for nuclear weapons positioning (Bhumitra Chukma, 2006). Descriptive blueprints define aim of WMDs budding, possession and broadcasts nuclear gestures to subdue and deter adversary (Frey, 2006). Nascent NWS preserve murkiness to construct and preserve WMDs warehouse, nuclear laboratories and complexes. Opacity subdues fear of enemy's decapitating strike and ascertains nuclear lifeline of NWS.

Nuclear doctrines are developed to deter aggression or deal with circumstances involving probable nuclear warfare (Lodgaard, 2011). Superpowers knew nuclear war cannot be won therefore, both treated WMDs as weapon of last resort. Mutual annihilation is consequently averted. Since atom bomb has its deterrent role, WMDs have been politically and psychologically used to get strategic interests. Genesis of India-Pakistan nuclear doctrines are traced back to the times of Cold War. Pakistan relies on WMDs for self-preservation. It does realize that WMDs should be used only as a last resort. Pakistan's nuclear ability has deterred Indian military from any aggression. Despite having entrenched political differences, the two republics have not aspired for any large-scale military adventure ever since the acquisition of nuclear capability. Sverre Lodgaard (2011) framed the term "political advantage," for exultant deterrent role of Pakistan's nuclear weapons. It is asserted hither efficacious practice of nuclear deterrent to preserve strategic objectives embedded sense of "virtual victory" in the psyche of Islamabad stationed bureaucrats. This doctrine stems from Pakistan's opposition to Indian declaration that South Asia falls in Indian sphere of influence (Mohan, 2003). Thirdly, Indian armed forces could not attack Pakistan in the aftermath of various crises. Pakistan opposed Indian coercive 
policy because Islamabad based bureaucrats firmly regard the radical perspective that tyrant must be resisted by the oppressed and consider it as a rational policy. Pakistan firm resolve to resist India with nuclear deterrent prevent Islamabad from signing the NPT as NNWS. India-Pakistan nuclear policies, arms race and vertical proliferation undermine universalisation of the NPT.

\section{The Development of Vajpayee's Nuclear Doctrine}

States exercise defensive or offensive strategies, asserts Scott D. Sagan (Sagan, 2009), depending upon its military muscles. In August, 1998, Indian Prime Minister Vajpayee became the architect of the Indian nuclear doctrine. Vajpayee nuclear doctrine was based on three pillars having a moderate nuclear posture.

a. Nuclear deterrent is imperative to certify Indian sovereignty and liberation.

b. India adheres to No-First Use (NFU).

c. India will neither threat nor resort to use atomic weapons against Nonnuclear Weapon States (NNWS)(Singh, 2010).

The Vajpayee doctrine claimed to provide negative security assurances to NNWS bordering India. On the basis of Vajpayee's doctrine this academicwork classifies Indian neighbors into three zones.

a. Chinese region: Vajpayee broadcasted nuclear signals to visualize and caution China that strategic changes are taking place in South Asian strategic sphere by saying that "deterrence... ensures Indian liberty... sovereignty," (Singh, 2010).

b. Pakistan specific Case: Second realism bestows acumen for Indian adherence to NFU designed for nuclear Pakistan. Conventionally, strong NWS avouch to mimic NFU policy against competing weak NWS (Sagan, 2009). Other explanations include India ache to put the onus of the outbreak of possible atomic war on Pakistan. India wants to sketch Pakistan WMDs programme as a threat to global peace and regional security. It aspires to declare Pakistan as an irresponsible NWS (Baruab, 2007) and bring it under pressure from international community.

c. South Asian NNWS: Third pillar, negative security assurances, is created to transmit high moral values to world civilization. India desires to receive admiration from world community that India is a responsible NWS. It does not pose threat to NNWS.

\section{Draft Indian Nuclear Doctrine}

Indian government established Strategic Advisory Board (SAB). It for the first time ever annexed troika of services chiefs (Frey, 2006), to facilitate Indian National Security Advisory Board to compile Draft Nuclear Doctrine. In 
August, 1999 First Draft on Indian Nuclear Doctrine (DIND) (Shinichi, 2003) was announced. It was agreed that (Dixit, 2002),

a. India would not use nuclear weapons to exploit its adversaries.

b. India would not indulge in arms race with its nuclear rivals China and Pakistan or any other state.

c. Possession of Indian nuclear weapons is meant to keep India intact, secure its borders from foreign aggression. India would also repel nuclear threats or coercive "political-strategic policy" backed by nuclear weapons of any state.

d. India is committed to the policy of nuclear disarmament therefore; India will unilaterally suspend future nuclear tests of all types.

e. India would abide by the principle of no first use. India would neither use its strategic weapons against Pakistan or any other nuclear or nonnuclear weapon state.

f. Indian nuclear programme is aimed to achieve the minimum credible deterrence.

g. Indian Prime Minister will take the decision to use nuclear weapons in self-defense.

h. Indian armed forces would be empowered with operational command and control system of nuclear programme.

Indian political system warrants Indian premier to oversee country's affairs with an authority to decide on strategic policy decisions. The strategic decisions are politically motivated likewise DIND was authored on the recommendations of political leaders'. The Draft empowered Indian Prime Minister the authority to control and launch nuclear attack if an essential. DIND was based on the principle of "punitive retaliation," should deterrence fail. Draft doctrine without determining minimum account of nuclear forces affirmed to amass a minimum nuclear deterrent to shield India. Minimum deterrent posture means deterrer possess survivable adequate nuclear forces to offset adversary's aggressive posture. Nuclear weapons deter enemy regardless of the magnitude and the nature of enemy's armed forces.

The DIND likewise Vajpayee nuclear doctrine aims at winning global appreciation owing to rhetoric that India would not indulge in arms race with regional adversaries. Indian credentials ascertain Indian policymakers Nehru, Indira Gandhi and Rajiv Gandhi supported efforts to see nuclear weapons free world for political motives i.e., to gain concessions from the West. Indian history certifies that aforementioned non-proliferation activists authorized the covert development of atom bomb. Rather, Indira Gandhi approved Peaceful Nuclear Explosions (PNE) in 1974. Rajiv issued directives to accelerate pace of WMDs development programme and made preparations for Hydrogen bomb (Chaudhry, 2017). Nonetheless, the above claim was confined to paper only.

\section{Indian Official Nuclear Doctrine}


On January 4, 2003 Cabinet Committee on Security (CCS) approved Indian official nuclear doctrine (IOND) (Saran, 2013). It consists of the following (India's Nuclear Doctrine: An Alternative Blueprint, 2012),

a. "Protecting the Indian state, from the use or threat of use of nuclear weapons by any state or entity, is the raison d'être of India's nuclear deterrent."

b. "India will not resort to the use or threat of use of WMDs against NNWS but such states shall be deemed NWS if they ally with or assist NWS against India, and or assist them during hostilities."

c. "India's nuclear deterrent is a manifestation of its right to self-defense as provided in Article 51 of the UN Charter."

d. "The Prime Minister (and his designated successors) shall exercise Command and Control over India's nuclear forces."

e. "Survival of the chain of command shall be ensured to provide leadership continuity in all eventualities."

f. "India will continue research on developing both delivery systems and warheads in the light of global technological advancements."

g. "India will be prepared to meet new challenges in ballistic missile defence, chemical, biological and radiological weapons that may have a bearing on its nuclear doctrine."

Indian reliance on nuclear deterrent to protect India or to thwart nuclear blackmail is a common attribute of DIND and IOND. New Delhi fearing two front nuclear dilemma from China and Pakistan orchestrated nuclear doctrine to transmit signals and deter them. The second common attribute of the Vajpayee, DIND and IOND is their adherence to NFU. India rejects nuclear first use. Paragraph I of the IOND asserts that "use of nuclear weapons... constitutes the gravest threat to humanity...to peace and stability in international system (Press Release, 2003). Paragraph V views that the "first use of nuclear weapons" as offensive. Indian government pledged to its opponents that New Delhi would not be the first to resort to the use or threat of use of WMDs during crisis/ war to impose its will or in pursuit to achieve political or strategic goals. The Prime Minister Narendra Modi reiterated that "No first use was a great initiative of Atal Bihari Vajpayee - there is no compromise on that. We are very clear. No the first use is a reflection of our cultural inheritance," (Busvine, 2014). Third, New Delhi provides negative security assurances to non-nuclear weapon states. Authors presume Indian in IOND replicated (Goldblat, 2003) negative security assurances given by US, France, UK and Russia to NNWS in pursuits to be lauded by international community.

IOND was slightly different than DIND e.g., First, IOND categorically warns that if India or Indian forces comes under attack from chemical, biological or radiological weapons (Press Release, 2003) anywhere it will use 
nuclear weapon against the attacker. The second, DIND asserts that if India absorbs nuclear first-strike it would respond with punitive massive retaliation.

\section{Transformation in Indian Nuclear Doctrine}

This section discusses three significant issues. The first, it highlights calls from Indian Nuclear Leftists and Rightists to discard NFU. The second segment highlights that new military technologies are encouraging Indian civilians and military government officials to pave the way for surgical/preemptive strikes against Pakistan.

\subsection{Calls for Review: Debate between Indian Nuclear Leftists and Rightists}

The development and preservation of assured the second strike nuclear forces, Buzan prescribes, is a prerequisite for deterrent forces (Buzan, 1987). India contrary to CMD is expanding nuclear complexes, producing weapons grade fissile material, increased production of delivery vehicles and nuclear warheads to complete nuclear triad. Indian quest to acquire second strike capability is driving Indian WMDs programme. New Delhi's vertical proliferation affirms the dichotomy between rhetoric and practical policy. Indian military capabilities are far from minimum capabilities required for defence purposes. India justifies its increased reliance on nuclear deterrent, continued vertical nuclear proliferation, conventional military superiority and revolution in military affairs (RMA) in the pretext to prepare for two-front war with Beijing and Islamabad. Indian defence budget and military capabilities remained higher as compared to Pakistan. New Delhi's favored conventional and economic asymmetry encouraged Indian former government officials to call for surgical/ preemptive strikes against Pakistan. It resulted in calls for change in IOND. Prominent former and incumbent government officials e.g., former Prime Minister Late Atal Bihari Vajpayee (Busvine, 2014), Professor P.R. Chari (Chari, 2014), Shivshankar Menon (Menon, 2016), military top brass for example former Strategic Forces Commander Lt. Gen B.S. Nagal (Joshi, 2016), former Defence Minister Manohar Parikar (Why Bind Ourselves to 'No First Use Policy, 2016), Satish Chandra(Chandra, 2014), incumbent Defence Minister Rajnath Singh, Indian analysts Ali Ahmed(Ahmed, 2016), Bharat Karnad (Kanwal, 2014), demanded of the government to review IOND. Likewise BJP's in its election manifesto criticized NFU. Doctrine was criticized on grounds that;

a. The NFU posture binds India to adopt defensive posture vis-à-vis the adversary.

b. Notion of massive retaliation in response to Pakistan's probable use of TNWs is considered inappropriate.

c. Advocates of change are skeptic of Indian willingness to use nuclear bomb on massive scale against TNWs. 


\subsection{Nuclear Leftists}

Indian government allocated US \$ 58 billion as defence budget in 2018. It is 2.1 percent of Indian gross domestic product (GDP)(India v/s Pakistan: Military Strength and Arsenal, 2019). India has 42 squadrons of jets, 814 combat aircrafts, Indian navy has one aircraft carrier, 16 submarines, 13 frigates, 75 combat aircrafts. Indian military has 3,565 tanks, 3100 infantry fighting vehicles, 336 armed personnel carriers, 9719 pieces of artillery and it has developed nine different types of missile capabilities (India v/s Pakistan: Military Strength and Arsenal, 2019). Missile types include cruise missiles, air launched, submarine launched tactical/battlefield, short range, medium range and intercontinental ballistic missiles (ICBMs). Consequentially, India enjoys upper hand vis-à-vis Pakistan. Conventional asymmetry huge military budget enables Indian armed forces to hit and destroy targets in any part of Pakistan. Ballistic Missile Defence (BMD) enables India to destroy incoming missiles, drones and fighter planes prior to reaching their targets. It provides false sense of security to security establishment in New Delhi. Indian hawks believe Indian nuclear posture inherits disadvantages e.g., it weakens Indian nuclear deterrent. NFU encourages the adversary to launch first strike against India. In the guise of NFU debate they propose preemptive strikes against Pakistan's counterforce assets. Indian security hawks are publically discussing inherited disadvantages of NFU. Indian cardinal society's criticism over IOND echo anxiety of Indian strategic hawks. Public debate serves the purpose to make public opinion in pursuit to pressure government and revoke NFU.

In 2018, India signed agreement worth $\$ 5.4$ billion US with Russia for the procurement of S-400 surface to air road-mobile missile system (Kuchay). It would receive first procurement by the end of 2021.Contract will endow New Delhi to receive ten battalions. Single battalion consists of eight launchers and 112 missiles (Qureshi, 2018). Delivery of this robust missile system would be completed by 2025 . S-400 surveillance radar has a range of 600 kilometers. Its missile's range is 400 Kilometers. Therefore, it is considered world's best anti-aircraft system (Ritzen, 2018). The 9M96E2 travels with the speed of Mach 15. It can engage the targets as low as five meters the above ground. S-400 can track 36 targets, adversary's missiles and combat aircrafts beyond its possessor's borders. It can destroy Pakistan's ballistic/cruise missiles, F-16s and JF-17 thunder combat aircrafts once operational. Longer range of radar system and higher precision strike rate enables it to be deployed away from the border and avoid preemptive or surprise strikes. S-400 will protect Indian Command and Control (C2) System, National Command Authority (NCA), military installations, major cities and nuclear complexes. Consequentially, it will tilt the strategic equation in India's favor.

New Delhi signed \$ 2.5 US billion agreement with Washington to procure 22 anti-tank Apache helicopters. Pakistan's AH-1F helicopter is no match to US supplied AH-64E (I) helicopters. (I), stands for India. It supports network centric aerial warfare. It can easily fly at a lower altitude to support fighting 
forces. Apaches can fire air to ground hellfire missiles, $70 \mathrm{~mm}$ hydra rockets and air-to-air stinger missiles to support Integrated Battle Groups (IBGs) under Cold Start Doctrine (CSD). Presumably, CSD is best suited to be operationalized against Pakistani targets in Punjab and Sindh provinces. AH64E helicopters night vision capability, beyond visual range missiles enables it to easily operate in mountainous areas of Kashmir. It will pose the existential threats to Pakistan's infantry soldiers.

Indian T-90MS tanks and Apache pose grave threats to Pakistan T-80UD battle tanks. Problems increased for Pakistan as Washington refused to provide AH-1Z helicopter. Pakistan was interested in purchasing T-129 gunship helicopters from Turkey. However, Washington has not authorized Istanbul the license for selling T-129's engines. Moscow under pressure from New Delhi also refused to sell Mi-35 gunship helicopters to Islamabad.

Indian military modernization and the overall strategic environment is widening the prevalent conventional gap between India-Pakistan and rising strategic temperature of South Asia. In turn Pakistan will have to rely on nuclear weapons for its defence. Conversely, nuclear hawks demand revolutionary changes in nuclear doctrine (Khan Z., 2020). For instance, NFU policy should be relinquished. This camp is named here as nuclear leftist (revisionists or revolutionaries). Non-proliferation community believes practically India relinquished its NFU policy (Pant \& Joshi, 202). Indian walkout from NFU will ripen ambiguous and erratic nuclear posture. It would have dire implications for strategic stability during peacetime. It would surely increase fear of preemptive strike during crisis and result in crisis instability during crisis. Indian walkout from NFU raises considerable questions about the circumstances in which India would resort to the first use after discarding NFU. Would India carryout preemptive first strike? Or India would resort to WMDs use owing to launch on warning? Whether Indian nuclear forces would target enemy's counter-value or counterforce targets? Is it going to adhere to deterrence by denial or deterrence by punishment model? By rejecting NFU the prerogative to launch nuclear strikes would be delegated to India's junior military officers of land, air and naval forces.

\subsection{Nuclear Rightists}

This group believes that India can deter Pakistan from launching proxies and exercising TNWs against India by retaining the NFU posture (Desai \& Desai, 2021). Therefore, they advocate preexistent nuclear doctrine or adhere to NFU, resist novelty, and call for developing assured second strike nuclear armory to launch massive retaliation in pursuit to punish the aggressor. However, authors believe that the alarming facet of the adherence to the concept of massive retaliation is that it embeds fear of obsolescence and encourages the adversary to carryout massive first strike instead of launching graduated response. Massive retaliation is an inappropriate against the use of TNWs as it creates crisis instability and destabilizes the region. A third group advocates that India should adopt policy based on graduated response. 
However, it would bring Indian Command and Control (C2) System under enormous pressure as Pakistan can slowly and gradually increase the use of nuclear weapons to destroy counter value targets in India (Clary \& Narang, 2018). In view of the above several Indians are advocating that either India should adopt a policy based on surgical strikes or adopt pre-emptive strikes to destroy counterforce targets in Pakistan.

\subsection{Calls for Pre-emptive/Counterforce Strikes}

In 2018, Clary and Narang claimed that Indian military developments indicate New Delhi's military capabilities exceed minimum forces required for retaliation. Secondly, India would launch counterforce (disarming) strikes against Pakistan's nuclear facilities in the future conflicts (Clary \& Narang, 2018). Clary and Narang highlights that India's erstwhile strategy based on the punitive massive retaliation targeted against counter value targets or city buster would be replaced with counterforce strikes. Perhaps change in Indian military strategy is taking place due to failure of the Indian scientists to develop thermonuclear weapons and not due to the technological advancement. Or New Delhi has already developed large caches of miniaturized nuclear weapons with low-yields to target Pakistan's counterforce targets. Advanced military technology India procured is followed by the proposals tabled by the former and incumbent government officials and the debate in Indian strategic community that India is moving towards counterforce strategy, surgical strikes or pre-emptive disarming strike is apparently an attempt to deliberately create ambiguity in the minds of adversaries.

Development of pre-emptive/ counterforce strikes is undoubtedly destabilizing the region. India maintains disassembled nuclear/ missile but preemptive strategy or counterforce temptations would require New Delhi to adopt ready or super-ready status. In this scenario, Indian political leaders would have to entrust the authority to launch nuclear triad (sea, land and air nuclear forces) to junior ranking military officers. It would result in first Indian political leadership would lose control over nuclear weapons. Second, the probability of unauthorized or accidental use or theft would also increase. Third, Indian nuclear weapons can also fall in the hands of Hindu extremists because of the rising Hindu extremism. Operationalization pre-emptive strategy requires India to ensure escalation dominance and to discard the NFU posture based on CMD. In 2018, Modi administration spent US $\$ 66.5$ billion as defence budget. It enabled India to become 4th biggest military spender (India Was 4th Biggest Military Spender Last Year, 2019). Indian procurement of military hardware will demand deployment of military forces, munitions depots, development of cantonments in close proximity to IndiaPakistan border and operationalization of the CSD to swiftly destroy counterforce targets in Pakistan.

Indian counterforce temptations stem from Indian belief that Pakistan maintains relatively small nuclear forces. Consequentially, India can destroy 
them in a disarming strike. However, it inherits problems. First, disarming strike cannot completely destroy/eliminate Pakistan's nuclear forces. After absorbing massive attacks against counterforce targets across the country Islamabad would definitely unleash nuclear forces against counter value targets in India. Is India ready to evacuate millions of Indian citizens from population centers due to the radiation? Can Indian government provide food, drinking water; medical treatment; control epidemics and shelters to its people? Second, Indian announcement of counterforce strategy would heighten Pakistan's existential threat. Fear of disarming strike in the midst of war would coerce Pakistan to carryout first strike against India. Third, fear of first strike heightens Indian security dilemma in turn it would encourage New Delhi to carryout pre-emptive strikes against Pakistan during crisis. Inevitably, it results in crisis instability.

\subsection{Calls for Surgical Strikes}

In this camp, mostly serving Indian government officials e.g., Director General Military Operations (DGMO) Lieutenant General Ranbir Singh, Indian Foreign Secretary Vijay Gokhale, former Chief of the Northern Command Lieutenant General (retd) D.S. Hooda (Surgical Strike Overhyped and Politicised, 2018), Lieutenant General (retd) Prakash Menon and India's serving COAS General Bipin Rawat (Bukhari, 2019), categorically advocate the surgical strikes against Pakistan. Calls for change in the Indian prevalent war fighting strategy to launch surgical strikes complicate South Asia's strategic landscape.

Indian rhetoric confirms that top Indian government officials including Indian National Security Advisor (NSA) Ajit Doval, the then Defence Minister Manohar Parikar, the then COAS Dalbir Singh Shuag and the then Chief of the Northern Command Lieutenant General Hooda in 2016, discussed to launch surgical strikes against Pakistan. Indian Prime Minister Modi knowing that Indian misadventure can cross Pakistan's nuclear threshold. Further, nuclear strings are attached with conventional war between IndiaPakistan yet surprisingly approved surgical strikes against Pakistan. Escalation rules call for carrying out nuclear first strike or warning shot in desert or mountain or sea or in airspace as warning shot. New Delhi carried out controversial surgical strikes first to call Pakistan's nuclear bluff or to checkmate Islamabad's nuclear deterrent. Second, perhaps to deliberately invite low yield nuclear first-strike to convince that world that Pakistan is a pariah state hence nuclear weapons should be stripped-off.

Lieutenant General Ranbir Singh, claimed that on September 29, 2016, India launched the surgical strike based on credible intelligence information against militant hideout in Pakistan (India Claims Striking Suspected Rebels in Pakistan, 2016). Hooda in-charge of the surgical strike asserted that "from military point of view the strike was much needed... bigger and better strikes." However, Islamabad refuted Indian claims (Khan, 2016). Undeniably India vis-à-vis Pakistan is gradually changing its military strategy. On September 
29, 2018 Rawat threatened Pakistan to get ready for another surgical strike (UPA conducted 3 surgical strikes but didn't show off: Rahul Gandhi, 2018). President of the Indian Congress Rahul Gandhi while addressing a public rally in September in Rajasthan also claimed that Prime Minister Man Mohan Singh authorized and the Indian military carried out three surgical strikes against Pakistan. Policy followed by claims for carrying out successful surgical strikes reflects Indian government's top brass assertive approach towards Pakistan. It reflects New Delhi's interest in India-Pakistan war.

On February 26, 2019 Vijay Gokhale claimed that Indian air force carried out the surgical strike in Balakot, Pakistan against alleged training camp of Jaish-e-Muhammad (JEM). Gokhale asserted that "pre-emptive strike became absolutely necessary," (Balakot: Indian Air Strikes Target Militants in Pakistan, 2019). In February, 2019 Al Jazeera quoted "India Today," that Indian military options include "shallow ground-based attacks and occupation of some heights along the Line of Control [ceasefire line] to restricted but precision air strikes against non-state targets in Pakistan-occupied Kashmir" (What are India's Options against Pakistan after Kashmir Attack? , 2019). India is acquiring capabilities to be able to launch pre-emptive strikes against counterforce targets in Pakistan. Prakash Menon in The Strategy Trap: India and Pakistan under the Nuclear Shadow (Siddiqi, 2019), endorsees the above claim that India is planning for pre-emptive strikes. Menon asserts that Pakistan could not be deterred by the surgical strikes so India should develop robust air force to use it against Pakistan. New Delhi has approached allies to gradually increase Indian military capabilities. US offered India to purchase unarmed Guardian surveillance drones, aircraft technologies and F-16 and F18 fighter aircraft (What are India's Options against Pakistan after Kashmir Attack?, 2019). In February, 2019 Lockheed Martin offered India to procure upgraded version of F-16 fighter jets designated F-21 fighter jets. Lockheed aspires to win a bid and supply 110 new fighter aircrafts to India (Gady, 2019). India signed agreement with France to procure thirty six multirole combat aircraft Rafale. It is capable of firing 2500 rounds per minute and long range missions. Rafale also has higher precision rate at sea and on land (Vikas Pandey, 2018). Once inducted in Indian air force will increase New Delhi's capabilities and tendency to carryout airstrikes in Pakistan near border.

Indian Chief of Army Staff (COAS) Rawat officially acknowledged the existence of CSD (Narang \& Ladwig III, 2017). Rawat coined the term Land Warfare Doctrine for swift limited action based on intelligence information against the enemy with support of Integrated Battalion Groups (IBGs) (Ullah, 2019). On January 10, 2019 Rawat reiterated that India is perfecting offensive war fighting strategy against Pakistan (Bukhari, 2019). This strategy is based on five features.

1. It aims at achieving military objectives through swift actions involving IBGs. 
2. It is based on element of surprise involving rapid IBGs from several directions. IBGs once operationalize would catch Pakistani forces by a surprise. Since, Pakistan has deployed tactical nuclear weapons (TNWs) near border so Pakistan would be faced with the either use it or lose it dilemma. Indian provocative strategy inherits the danger of crossing Pakistan's nuclear threshold.

3. This military strategy offensive in nature therefore it aspires to take the war into enemy's territory.

4. This provocative strategy aims at horizontal escalation or expanding theater of war from land to air to ocean. This feature was observed during Pulwama/Balakot Crisis. Indian Prime Minister Narendara Modi blatantly called for planning "Qatal-ki-Raat," threatened that India was planning to fire missiles against Pakistani cities. Further, Pakistan navy detected Indian submarine near its coastal areas.

5. It aspires to quickly seize Pakistani territory and hold it as a bargaining chip. Rawat highlighted he aims to prepare Indian military for future wars by equipping it with latest military technology. Second, better manage Indian military defence budget and third above all prepare Indian army against Pakistan (Bukhari, 2019). Indian deployment of T90 tanks near Pakistani border endorses Rawat's claim. T-90 tank is equipped with night visions, anti-tank guided missiles, high explosive guns and strong maneuverability (Ullah, 2019). Indian military is also working on Network Centric Capabilities (Warfare Doctrine) to connect its soldiers during operations, swiftly achieve military objectives and avoid collateral damage.

\section{Conclusion}

Findings of this academic research is Indian qualitative changes, massive defence budget and quest to guarantee escalation dominance augmented Pakistan's prevalent security dilemma and fear of existential threat to Pakistan. India-Pakistan adversarial relationship and unsettled border dispute breeds regional instability. Indian nuclear weapons fuel abhorrence, hostility and regional arms race. It posed decision makers in Beijing and Islamabad with security dilemma. India nuclear weapons are perpetual source of horizontal and vertical nuclear proliferation in South Asia. New Delhi's nuclear ambitions and rejection of the NPT provoked Pakistan to reject the NPT and develop nuclear weapons for deterrent purposes. Indian nuclear ambitions scrapped the NPT in South Asia and obstructed the implementation of Article VI of the NPT globally. The author claims that Indian nuclear weapons programme undermined the spirit of the NPT from outside and pose internal challenges to the treaty.

IOND repeats NATO's nuclear weapons use strategy and concept of massive retaliation adhered by the US Defence Department as comparable nuclear strategy in 1990(Mendelsohn, 1999). Massive retaliation is a dangerous strategy as Pakistan adheres to First Use Policy (FUP). The first use 
of the WMDs is neither time-bound nor by the type of war. It is developing and may presumably use TNWs to express resolve and pledge in an attempt to transmit message. Probable use of TNWs at minor level by Pakistan is known as graduated response in literature available on nuclear war fighting and strategy. If Indian forces did not stop its maneuver intensity of nuclear weapons use would be gradually intensified. But IND would force India to respond with massive retaliation. On the other hand, fear of massive retaliation may thereupon force Pakistani policymakers to authorize decapitating first strike against India instead of graduated response. However, Indian ability to gather leftover nuclear forces would surely result in massive retaliation. Since, both sides cannot leave anything to chance, fear of reciprocative massive retaliation in the minds of Indian and Pakistani policymakers would continue to persist (Ahmed). IND based on massive retaliation strategy generates uncertainty, disturbs strategic and crisis stability and scrap the philosophy of limited nuclear war.

\section{Reference}

Ahmed, A. (2016, December 13). India's Nuclear Doctrine: Coming Out of the Closet. Foreign Policy Journal. Retrieved from: http://www.foreignpolicyjournal.com/2016/12/13/indias-nucleardoctrine-coming-out-of-the-closet/

Ahmed, A. (n.d.). Rethinking India's Nuclear Doctrine. Retrieved from http://fsss.in/agni-volume/2nd/rethinking-india's-nuclear-doctrine.pdf

Baruab, A. (2007). Dateline Islamabad. New Delhi: Penguin Books.

Bhumitra Chukma. (2006, July). Pakistan's Nuclear Doctrine, and Command and Control System: Dilemmas of Small Nuclear Forces in the Second Atomic Age. Security Challenges, 2(2), 115.

Bukhari, S. S. (2019, January 26). Overviewing India's Military Modernization: 2019 and Beyond. Modern Diplomacy. Retrieved from: https://moderndiplomacy.eu/2019/01/26/overviewing-indias-militarymodernization-2019-and-beyond/

Busvine, D. (2014, April 16). India's Modi Says Committed to No First Use of Nuclear Weapons. Reuters. Retrieved from: https://www.reuters.com/article/us-india-election-nuclearidUSBREA3F15H20140416

Buzan, B. (1987). An Introduction to Strategic Studies: Military Technology and International Relations. Hampshire: International Institute for Strategic Studies.

Chandra, S. (2014, April 30). Revisiting India's Nuclear Doctrine: Is It Necessary? Institute for Defence Studies and Analyses, Issue Brief. Retrieved 
http://www.idsa.in/issuebrief/RevisitingIndiaNuclearDoctrine_Schandr a_300414

Chapman, B. (2009). Military Doctrine: A Reference Handbook. Santa Barbara: Pager Security International.

Chari, P. (2014, June 4). India's Nuclear Doctrine: Stirrings of Change. Carnegie Endowment for International Peace. Retrieved from: https://carnegieendowment.org/2014/06/04/india-s-nuclear-doctrinestirrings-of-change-pub-55789

Chaudhry, D. R. (2017, January 24). Under Rajiv Gandhi, India Was Ready with H-Bomb to Counter Pakistan's Nukes. The Times of India. Retrieved from: https://m.economictimes.com/news/politics-andnation/under-rajiv-gandhi-india-was-ready-with-h-bomb-to-counterpakistans-nukes/articleshow/56743176.cms

Clary, C., \& Narang, V. (2018, Winter). India's Counterforce Temptations: Strategic Dilemmas, Doctrine, and Capabilities. International Security, $40(3), 8,9$.

Dixit, J. N. (2002). India-Pakistan in War and Peace. New York: Routledge.

Frey, K. (2006). India's Nuclear Bomb and National Security. Oxon: Routledge.

Gady, F.-S. (2019, February 21). Lockheed Martin Offers India Upgraded F16 Fighter Jet. The Diplomat. Retrieved from: https://thediplomat.com/2019/02/lockheed-martin-offers-indiaupgraded-f-16-fighter-jet/

Goldblat, J. (2003). Arms Control: The New Guide to Negotiations and Agreements. Solona: SIPRI.

Joshi, M. (2016, November 11). Weighing the Benefits of Recalibrating India's Nuclear Doctrine. The Wire. Retrieved from: https://thewire.in/79461/weighing-the-benefits-of-recalibrating-indiasnuclear-doctrine/

Kanwal, G. (2014, December 5). India's Nuclear Doctrine: Need for a Review. CSIS.

Khan, M. I. (2016, October 23). India's Surgical Strikes in Kashmir: Truth or Illusion? $B B C$ News. Retrieved from: https://www.bbc.com/news/world-asia-india-37702790

Kissinger, H. (1957). Nuclear Weapons and Foreign Policy. New York: Harper and Brothers.

Kuchay, B. (n.d.). Russian S-400 missile delivery to India by end of 2021: Official. $A l$ Jazeera. Retrieved from: https://www.aljazeera.com/news/2020/02/russian-400-missiledelivery-india-2021-official-200205082528342.html

Lodgaard, S. (2011). Nuclear Disarmament and Non-Proliferation: Towards a Nuclear-Weapon-Free-World? New York: Routledge.

Mendelsohn, J. (1999, July/August). NATO's Nuclear Weapons: The Rationale for 'No First Use. Arms Control Association. Retrieved from: http://www.armscontrol.org/act/1999_07-08/jmja99 
Menon, S. (2016). Choices: Inside the Making of India's Foreign Policy. Washington, D.C.: Brookings Institution Press.

Mohan, C. R. (2003, January 2). Beyond India's Monroe Doctrine. Ministry of External Affairs. Retrieved from: http://mea.gov.in/articles-in-indianmedia.htm?dtl/15281/Beyond+India+s+Monroe+Doctrine

Narang, V., \& Ladwig III, W. C. (2017, January 11). Taking 'Cold Start' Out of the Freezer. The Hindu. Retrieved from: https://www.thehindu.com/opinion/lead/Taking-\%E2\%80\%98ColdStart\%E2\%80\%99-out-of-the-freezer/article17019025.ece

Qureshi, A. (2018, December 19). India-Russia S-400 Deal: Implications on Pakistan and China. The Fortress. Retrieved from: https://thefortress.com.pk/india-russia-s-400-deal-implications-onpakistan-and-china/

Ritzen, Y. (2018, October 8). Why Do Countries want to Buy the Russian S400? Al Jazeera. Retrieved from: https://www.aljazeera.com/indepth/features/countries-buycontroversial-russian-400181007205808578.html?utm_source=website\&utm_medium=article_p age\&utm_campaign=read_more_links

Sagan, S. D. (2009). The Evolution of Pakistan and Indian Nuclear Doctrines. In S. D. Sagan, Inside Nuclear South Asia (p. 222). Stanford: Stanford University Press.

Saran, S. (2013, April 24). Is India's Nuclear Deterrent Credible?" Delivered at Habitat Centre. 12. New Delhi.

Sauer, T. (2009, October). A Second Nuclear Revolution: From Nuclear Primacy to Post-Existential Deterrence. The Journal of Strategic Studies, 5(32), 746.

Sethi, M. (2004). Devaluing Nuclear Weapons: Difficult, But Desirable. In J. S. Sethi, Nuclear Deterrence and Diplomacy (p. 75). New Delhi: Knowledge World.

Shinichi, I. M. (2003). The Nuclear Policy of India and Pakistan. NIDS Security. NIDS Security Report.

Siddiqi, A. B. (2019, March 16). India-Pakistan Tensions: A Strategic Insight. The News.

Singh, R. (2010, July-December). Nuclear Weapons as a Deterrent in South Asia: An Analysis. Asia Pacific Journal of Social Science, II (2), 38.

Synnott, H. (1999). Nuclear Capabilities, Nuclear Doctrines. The Adelphi Papers, 39 (332), 53.

Ullah, Z. (2019, August 7). Revamping Indian Military Modernization: Challenges and Implications for Pakistan's National Security- OpEd. Eurasiareview News \& Analysis. Retrieved from: http://www.eurasiareview.com/07082019-revamping-indian-militarymodernization-chal 
Vikas Pandey. (2018, September 26). Rafale Deal: Why Fench Jets Are at the Centre of an Indian Political Storm. BBC News. Retrieved from: http://www.bbc.com/news/world-asia-india-45636806

Cabinet Committee On Security Reviews Progress in Operationalizing India's Nuclear Doctrine. (2003, January 4). Retrieved from: http://www.pib.nic.in/archieve/Ireleng/lyr2003/rjan2003/04012003/r04 0120033.html

National Security Strategy. (2010, May). Retrieved from: http://www.whitehouse.gov/sites/default/files/rss_viewer/national_secu rity_strategy.pdf

India's Nuclear Doctrine: An Alternative Blueprint. (2012). 4,5. Institute of Peace and Conflict Studies.

India Claims Striking Suspected Rebels in Pakistan. (2016, September 29). Al Jazeera. Retrieved from: https://www.aljazeera.com/news/2016/09/india-claims-strikingsuspected-rebels-pakistan-160929072504037.html

Why Bind Ourselves to 'No First Use Policy,' Says Defence Minister Parikar on India's Nuclear Doctrine. (2016, November 10). Times of India.

Surgical Strike Overhyped and Politicised, Says General Who Oversaw Operations. (2018, December 8). India Today.

UPA conducted 3 surgical strikes but didn't show off: Rahul Gandhi. (2018, December 1). Hindustan Times.

Balakot: Indian Air Strikes Target Militants in Pakistan. (2019, February 26). BBC News. Retrieved from: https://www.bbc.com/news/world-asia47366718

India vs Pakistan: Military Strength and Arsenal. (2019, February 26). Al from: https://www.aljazeera.com/news/2019/02/india-pakistan-militarystrength-arsenal-190226064227556.html

India Was 4th Biggest Military Spender Last Year. (2019, May 1). Hindustan Times. Retrieved from: http://www.m.hindustantimes.com/india-news/ india-was-4th-biggest-military-spender-last-year/story9YnXVnRsXQaTtt1cxdsiL.html

What are India's Options against Pakistan after Kashmir Attack? (2019, February 16). Al Jazeera. Retrieved from: https://www.aljazeera.com/news/2019/02/india-options-pakistankashmir-attack-190216164936295.html 